\title{
The Application of Multimedia Humor in Malay Language Narrative Writing
}

\author{
Norul Haida Bt. Reduzan
}

\begin{abstract}
By adopting a Dick and Carey model, thepurpose of this study was to develop a multimedia humour model for the teaching of Malay narrative writing and test the effectiveness of the model in the classroom. This study was conducted to a group of 29 students at SekolahMenengahKebangsaan Syed Mashor, Batang Kali, Selangor. The research design was quasi experimental involving single group pre-test and post-test design. Following this design, participants were selected, pre-tested, and exposed to the multimedia video (animation) and then post-tested. The instrument used in this research was the writing test on Malay narrative focusing on cleanliness. Descriptive quantitative analysis was employed on the findings (frequency, percentage and mean) followed by a comparison of pre-test and post-test. The findings show that there were significant differences between the pre and post-test. In the post-test, the mean score for the participants after receiving the intervention were higher than the mean scores for the pre-test. The findings also reveal that the use of visual images (animation), sound and graphic through multimedia video for teaching Malay narrative writing help the students to improve their vocabularies and writing skills. Thus, teachers may also adopt this type of learning approach to attract student's attention towards the subject and hence, improve their academic performance of a particular subject.
\end{abstract}

Key word:Humor Model; Multimedia; Writing; Narrative; Malay Language

\section{INTRODUCTION}

One of the most important aspects of an independent state in building a successful and developing nation is to develop the mindset of its' people. Sadly, due to the current wave of globalization; the role of Malay Language seems to have been forgotten. According to AwangSariyan (2005), predominant and important languages of the world are closely related to the rise of political power, economy, trade, education and other fields of the civilization of a nation. In addition, ZaitulAzmaHamzah (2006), explains that the Malay language needs to reach the economical status by exploring global fields, industries, science, technology, engineering and aerospace.

\section{Research Objective}

Based on the researchproblem, the researcher has introduced an objective :

To develop a multimediahumor model fortheteaching of narrative writing.

\section{LITERATURE HIGHLIGHTS}

According to Miura and Jones (2005) of the Wake Forest University, through their research The Use of Humor in Secondary Social Studies Classrooms (2005); jokes is a very attractive and useful tool in a classroom. However, after analysing the theory of Miura and Jones (2005), it is found that jokes should not be used as one pleases. Abbot (2003), found that nearly $73 \%$ of jokes by teachers are not related to the learning process. Besides, he also researched the negative impacts of jokes used by teachers. The other component of this research is to determine the frequency of jokes by teachers in a normal classroom, and an advanced or a standard classroom. Jokes is a vague concept to be arranged and measured accurately. Abbot (2003), identifies dan classifies jokes at university and secondary school levels. He mentions that he was actively involved in data collection, observing the learning process at secondary schools and invented his own taxonomy.

\section{The Systematic Teaching Design of Dick and Carey}

The Dick and Carey Model has an important contribution in the teaching design by focusing to the relation between context, content, learning and teaching (Dick, Carey, \& Carey, 2009).

According to Dick et. al, (2009), components such as trainers, learners, materials, teaching activities, learning environment and the learning achievements interacts between one another to ensure the achievement of learning outcomes. Based on Figure 1, Dick et. al, (2009) deduces that there are 10 main components in the systematic teaching design, as following: 


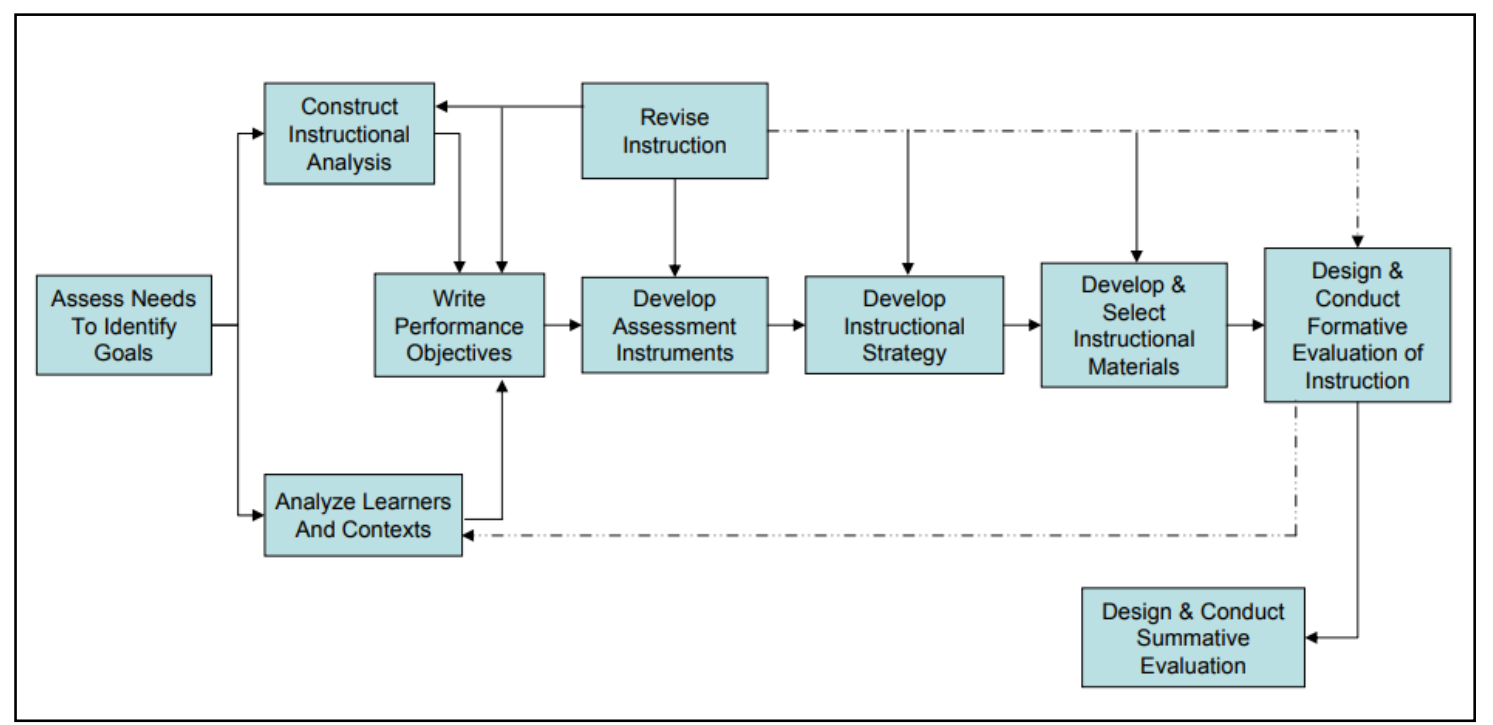

Fig. 1 The Systematic Teaching Design ofDick dan Carey (Source: Dick et al., 2009)

The Development of Multimedia Humor in the Teaching of Narrative Writing in Malay Language

In accordance to the current development, multimedia offers the technological capacity to help design teaching which cultivates creative and critical thinking and improves writing skills (RozinahJamaludin, 2005). The development of this model has gone through certain phases whereby it needs to undergo testing processes. This includes the verification being executed by an expert from the related field and the model being tested in classrooms to perceivethe effectiveness of the model in teaching narrative writing in Malay Language.

\section{Findings}

Collection of data was held one more time to strengthen the previous findings. Therefore, a second post test was held to reaffirm the understanding of learners in producing a complete narrative entitled "The Classroom Environment" based on the framework built.

Table . 1 Marks and Mastery Level of Students

\begin{tabular}{|c|c|c|c|c|c|}
\hline \multirow[b]{2}{*}{ Students } & \multicolumn{5}{|c|}{ Total Marks } \\
\hline & $\begin{array}{l}\text { 1-6 } \\
\text { (Weak) }\end{array}$ & $\begin{array}{l}7-12 \\
\text { (Satisfactory) }\end{array}$ & $\begin{array}{l}\text { 13-18 } \\
(\text { Good })\end{array}$ & $\begin{array}{l}19-24 \\
\text { (Very Good) }\end{array}$ & $\begin{array}{l}\mathbf{2 5}-\mathbf{3 0} \\
\text { (Excellent) }\end{array}$ \\
\hline Boys & 0 & 11 & 4 & 1 & 0 \\
\hline Girls & 0 & 3 & 5 & 3 & 2 \\
\hline \multirow{2}{*}{ Total } & 0 & 14 & 9 & 4 & 2 \\
\hline & \multicolumn{5}{|l|}{29} \\
\hline Average & \multicolumn{5}{|l|}{14.7} \\
\hline
\end{tabular}

Table 1 - Post Test 1 Marks of Form 2 Gigih students for Malay Language Narrative Writing section entitled "Personal Hygiene" 


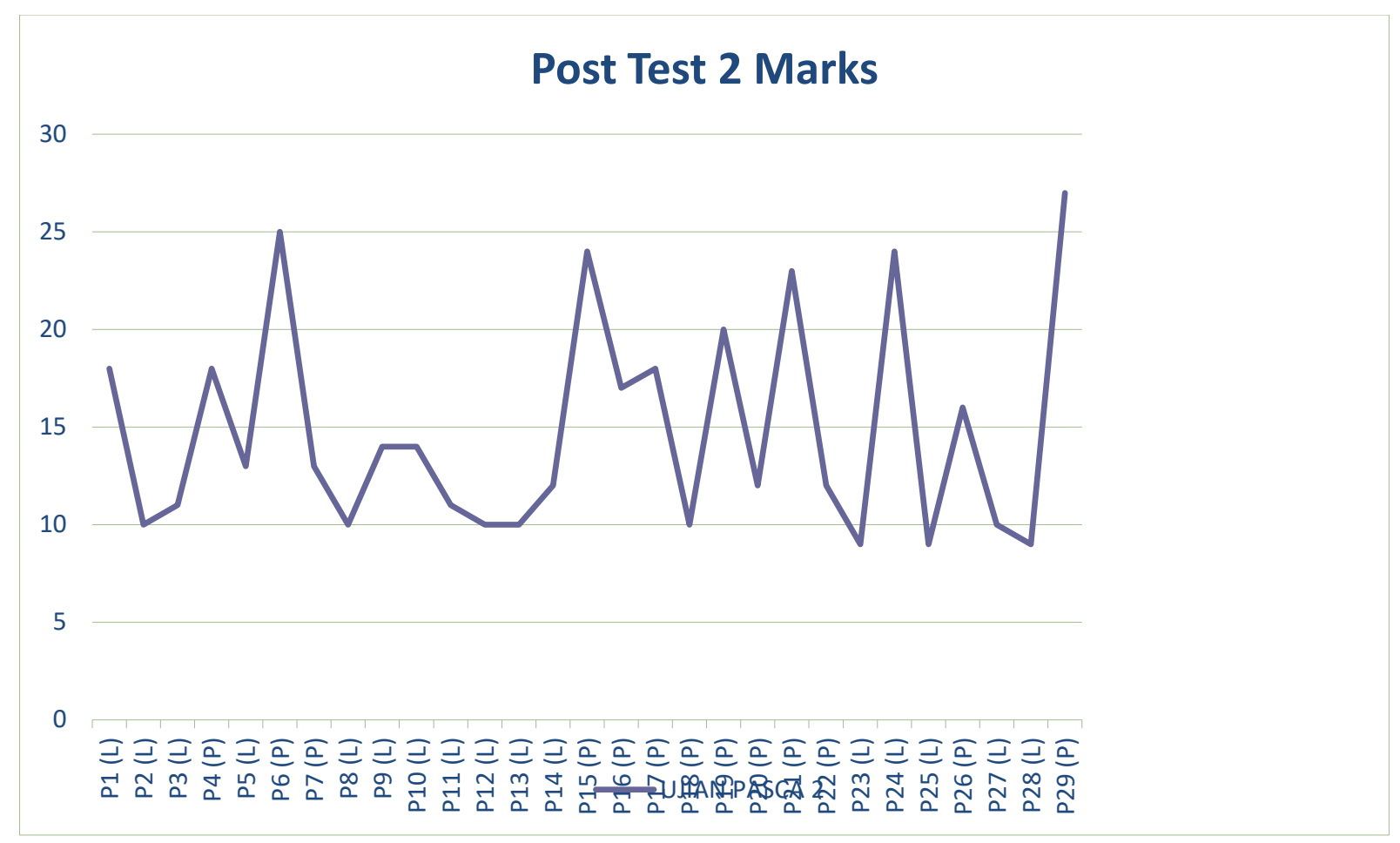

Fig. 2 Line graph showing achievement of each student in Post Test 2

Based on the analysis of Post Test 2 marks, there was a significant improvement in students' achievement in Malay Language narrative writing. Table 1 shows that there are no students with 6 or lesser marks; which is under the Weak category. 14 students are in Satisfactory level; 7 to 12 marks. This is followed by 9 students in Good category. 5 of them are girls and 4 boys. 4 students are under the Very Good category with marks of 19 to 24 . Finally, 2 students whom scored 25 to 30 marks are in Excellent category. The average marks of Post Test 2 had increased by 14.7

\section{CONCLUSION}

In conclusion, this research has proven that the development, verification, and the effectiveness of Multimedia Humor Model in the teaching of narrative writing in Malay Language is very important. Although the curriculum prepared by Curriculum Development Centre (Pusat Perkembangan Kurikulum) is considered succesful in strengthening the learning of Malay Language; this research proves that application of multimedia humor in Malay Language contains certain weaknesses. This includes the variation of humors introduced to students which are not helping students to improve their Malay Language. Some texts and passages being used are found to be not suitable and irrelevant, as well. After taking all these aspects into consideration, a new curriculum was proposed to be executed. This curriculum is hoped to be whole and could ensure the improve in the mastery of Malay Language in secondary schools. Students need to have a behavioral change and take into consideration the usage and mastery of the Malay Language completely. The language efficiency among students needs a long time and a consistent practice. Therefore, the attitude of students assuming that Malay Language is an easy language simply because it is used in daily communication should be changed. To be an efficient language user, students should understand that ample of time is needed.

\section{BIBLIOGRAPHY}

1. Abbott, S. (2003). No, Seriously: Humor use by High School Social Studies Teachers. In L.P. McCoy (Ed.) Studies in Teaching 2003 Research Digest (p.1-5) Winston-Salem, NC: Wake Forest University Department of Education.

2. AwangSariyan. (2005). PengajaranTerancang Kata PinjamanbahasaInggerisMemperkayaKosa Kata PelajarbahasaMelayu. InstitutPendidikan Sultan HassanolBolkiah: Universiti Brunei Darussalam.

3. Dick dan Carey dalamLamudji. (2005). Pengaruh Media PembelajaranTerhadapHasilBelajarPengelasanpadaSiswa yang BerprestasiTinggidanRendah di SMK SwastaSatuTrisaktiLaguboti. Kobupaten: Toba Samosir.

4. Miura dan Jones. (2005). Gendered Discourse at Work. New York: Routledge.

5. RozinahJamaluddin, (2005) ESP Today: A Practitioner's Guide. New York: Prentice Hall.

6. ZaitulAzmaZainonHamzah.

(2000).

PenggunaanBahasadalamPertuturanKanakSatuAnalisisPragmatik. TesisSarjana. Universiti Putra Malaysia. 